Volume 4 No. 2 November 202

\title{
Application of Analytic Hierarchy Process and Weighted Product Methods in Determining the Best Employees
}

\author{
Sri Harjanto ${ }_{1,2,3}$, Setiyowati $^{2}$, and Retno Tri Vulandari ${ }^{3}$ \\ ${ }_{1,2,3}$ STMIK Sinar Nusantara Surakarta \\ retnotv@sinus.ac.id
}

\begin{abstract}
Employees are one of the company's assets that must be managed properly. Therefore the selection of the best employees is now needed. The problem faced in determining the best and qualified employees is that there are still no standards in assessing only one person subjectively in determining the best employee, which consequently lacks appropriate or objective results. To provide rewards for the best employees, we need a system to support the decisions of the best employees who deserve to receive rewards to be on target. The purpose of this research is to design and build a decision support system application in determining the best employees using the analytic hierarchy process and weighted product methods. Stages of software development of the Software Development Life Cycle (SDLC) uses a waterfall, that is data analysis, system design, construction, coding, testing and implementation. The results of this process are in the form of calculation applications that have been obtained from the analytic hierarchy process and weighted product methods in determining the best employee. The result gives an accuracy rate of $82.3 \%$.
\end{abstract}

Keywords: analytic hierarchy process, weighted product, decision support system, employees

\section{Introduction}

Employees are one of the company's assets that must be managed properly. Therefore, the selection of the best employees at this time is necessary. Some employees held competitions to get the best employee rewards, which are expected to improve employee performance. The process of determining the best employees is based on an assessment of their presence, performance, abilities, attitudes and cooperation. The problem faced by the Enggal Waras Clinic in determining the best and quality employees is that there is still no standard in the assessment of only one person subjectively in determining the best employee, which consequently lacks appropriate or objective results So, to overcome these obstacles, a decision support system is needed to determine the best employees. The proposed method is Analytic Hierarchy Process (AHP) and Weighted Product (WP).

The decision-making system is built using several methods or even models that are currently trending, namely the Analytical Hierarchy Process (AHP) and Weighted Product (WP) methods. Analytical Hierarchy Process (AHP) is a method of measurement used to determine the ratio scale by performing pairwise comparisons of each factor. 
Pairwise comparisons can be determined through intuition, actual and relative measurements, degree of importance, level of preference, experience and a person's facts, which are basic scales that show relative strengths and preferences [1]. While the weighted product is a structured decision method. This method includes a performance appraisal process starting from the weighting of the criteria to determine the weight of each to solve the problem of Multi Attribute Decision Making (MADM) [2]. WP uses multiplication to connect attribute ratings, where the rating of each attribute must be raised to the first power with the weight of the attribute in question, this process is the same as the normalization process.

The purpose of this research is to design and build a decision support system application in determining the best employees using analytic hierarchy process and weighted product methods. AHP method is a structured decision making model. This method includes a performance appraisal process starting from the weighting of the criteria to determine the weight of the importance of each indicator, then the indicators that can produce alternative weights to determine the highest value of the available alternatives. The Weighted Product (WP) method is based on its ability to provide solutions as a method for alternative ranking [3].

\section{Literature Review}

Research on determining the location of product marketing using the analytic hierarchy process and weighted product methods in Bali has been done. Methods of analytical hierarchy process and weighted product in the process of determining the location of product marketing are more efficient so that the developer is faster in the process of making objective decisions [4].

Another research using the analytical hierarchy process and weighted product methods at STMIK Balikpapan has also been carried out. Accuracy with the AHP and WP calculation process resulted in an output in the form of a ranking of each lecturer individually from the highest to the lowest. This is used as supporting material and consideration in determining decisions, such as the feasibility of teaching educators/lecturers and providing rewards [5].

Research on decision support systems to determine the appropriateness of permanent employment using the AHP and WP method at the staffing section of PT. Kwanglim YH Indah has been done with the addition of some criterias such as attendance, discipline, years of service, skills, work experience and teamwork. The 
analytic hierarchy process method as the determination of the weight for each criterion and the weighted products method as a method for ranking alternatives were used for determining the appropriateness of the appointment of contract employees to be fixed [6].

Research on the decision support system for high school teacher performance appraisal in Bandung has been done by using AHP and WP methods. These methods can be applied to the case of teacher performance appraisal because the weight will be easily determined as to which criteria or competency assessment needs to be sought or owned by the teacher, as the principal wants to need this condition for the purposes of career development, rank, and teacher position. and a ranking process that resulted in alternatives that the principal could consider [7].

Decision support system for determining the best village in Cianjur Regency has been carried out by combining the analytic hierarchy process and weighted product methods which have relevant results in decision making. The combination of the AHP and WP methods can produce a more stable rating and less subjectivity [8].

\section{Results and Discussion}

3.1 AHP Method Settlement. The calculation process uses the analytic hierarchy process and weight product methods in the decision support system to determine the best employees. We use data from the Enggal Waras Clinic.

1. It is known that there are four nurses at the Enggal Waras Clinic. There are five criteria, namely Presence (C1), Performance (C2), Ability (C3), Attitude (C4), Cooperation (C5). The data can be seen in Table 1.

Table 1. Employee Assessment Data

\begin{tabular}{llllll}
\hline Alternative & Presence & Performance & Ability & Attitude & Cooperation \\
\hline Employee 1 & 95 & Not Good & Enough & Enough & Enough \\
Employee 2 & 80 & Enough & Well & Not Good & Very Good \\
Employee 3 & 92 & Enough & Not Good & Enough & Well \\
Employee 4 & 62 & Well & Enough & Well & Enough \\
\hline
\end{tabular}

2. Determine the weight of the importance of each existing criterion. The results can be seen in Table 2.

3. Enter the weight value of the pieces in the pairwise comparison table. The results can be seen in Table 3 . 
Table 2. Criteria Weights for Each Interest

\begin{tabular}{cc}
\hline Criteria & Interests \\
\hline C1 & 1 \\
C2 & 1 \\
C3 & 3 \\
C4 & 3 \\
C5 & 5
\end{tabular}

Table 3. Pairwise Comparison Matrix

\begin{tabular}{cccccc}
\hline & $\mathrm{C} 1$ & $\mathrm{C} 2$ & $\mathrm{C} 3$ & $\mathrm{C} 4$ & $\mathrm{C} 5$ \\
\hline $\mathrm{C} 1$ & 1 & 1 & $1 / 3$ & $1 / 3$ & $1 / 5$ \\
$\mathrm{C} 2$ & 1 & 1 & $1 / 3$ & $1 / 3$ & $1 / 5$ \\
$\mathrm{C} 3$ & 3 & 3 & 1 & 1 & $1 / 3$ \\
$\mathrm{C} 4$ & 3 & 3 & 1 & 1 & $1 / 3$ \\
$\mathrm{C} 5$ & 5 & 5 & 3 & 3 & 1 \\
\hline
\end{tabular}

4. Perform normalization on the pairwise comparison matrix. This step divides the value of each cell by the number of columns in each criterion, so that the weight vector $(W)$ of each criterion is obtained. The results can be seen in Table 4 .

Table 4. Normalization and Weight Criteria

\begin{tabular}{cccccccc}
\hline & $\mathrm{C} 1$ & $\mathrm{C} 2$ & $\mathrm{C} 3$ & $\mathrm{C} 4$ & $\mathrm{C} 5$ & Total & $W$ \\
\hline $\mathrm{C} 1$ & 0.349 & 0.349 & 0.36 & 0.36 & 0.294 & 1.713 & 0.342 \\
$\mathrm{C} 2$ & 0.349 & 0.349 & 0.36 & 0.36 & 0.294 & 1.713 & 0.342 \\
$\mathrm{C} 3$ & 0.116 & 0.116 & 0.12 & 0.12 & 0.176 & 0.647 & 0.13 \\
$\mathrm{C} 4$ & 0.116 & 0.116 & 0.12 & 0.12 & 0.176 & 0.647 & 0.13 \\
$\mathrm{C} 5$ & 0.07 & 0.07 & 0.04 & 0.04 & 0.059 & 0.277 & 0.056 \\
Total & 1 & 1 & 1 & 1 & 1 & 5 & 1 \\
\hline
\end{tabular}

Table 5. Multiplication result of priority weights

\begin{tabular}{cc}
\hline Criteria & Consistency Vector $\left(W^{*} A x\right)$ \\
\hline $\mathrm{C} 1$ & 5.02 \\
$\mathrm{C} 2$ & 5.02 \\
$\mathrm{C} 3$ & 5.05 \\
$\mathrm{C} 4$ & 5.05 \\
$\mathrm{C} 5$ & 5.13 \\
Total & 25.28 \\
\hline
\end{tabular}


5. Perform a consistency check for the pairwise comparison matrix values by finding the maximum eigen value $(\lambda \max )$. This can be seen in Table 5 .

6. After the maximum eigen value $(\lambda \max )$ is found the next step is to calculate the Consistency Index (CI) value:

$$
\mathrm{CI}=\frac{5.06-(5)}{5-1}=0.01
$$

7. The last stage is calculating the Consistency Ratio $(\mathrm{CR})$ value:

$$
\mathrm{CR}=\frac{0.01}{1.12}=0.012 \sim 0.01
$$

If $\mathrm{CR} \leq 0.1$, the comparison results from the matrix are stated to be consistent.

3.2 WP Method Settlement. The following are some steps in WP Method.

1. Determine the value of preference weight $(W)$ in each criterion with no recalculation.

Because the weight value $(W)$ has been obtained at the calculation stage using the AHP method, in the WP process it is not recalculated.

$W=(0.342,0.342,0.129,0.129,0.056)$

2. Calculate the preference value for alternatives:

$S_{i}=\Pi_{j=1}^{n} X_{i j}^{w_{j}}$

with $S_{i}=$ preference value for alternatives, $X_{i j}=$ alternate rating of each attribute, $W_{j}=$ weight of attribute, $i=$ alternative $(i=1,2,3, \ldots, \mathrm{n}), j=$ criteria, $n=$ number of criteria.

$$
\begin{aligned}
& S_{0}=\left(5^{0,342}\right)\left(2^{0,342}\right)\left(3^{0,129}\right)\left(3^{0,129}\right)\left(3^{0,055}\right)=3.11031401 \\
& S_{1}=\left(4^{0,342}\right)\left(3^{0,342}\right)\left(4^{0,129}\right)\left(2^{0,129}\right)\left(5^{0,055}\right)=3.35468218 \\
& S_{2}=\left(5^{0,342}\right)\left(3^{0,342}\right)\left(2^{0,129}\right)\left(3^{0,129}\right)\left(4^{0,055}\right)=3.44591391 \\
& S_{3}=\left(3^{0,342}\right)\left(4^{0,342}\right)\left(3^{0,129}\right)\left(4^{0,129}\right)\left(3^{0,055}\right)=3.43651611
\end{aligned}
$$

3. Calculate the vector value $V$ is the last step in the weighted product method, the vector value $V$ is sought to perform the ranking process,

$$
\begin{aligned}
& V_{i}=\frac{\prod_{j=1}^{n} X_{i j}^{w_{j}}}{\prod_{j=1}^{n}\left(X_{i j}{ }^{*}\right)^{w_{j}}} \\
& V_{0}=\frac{3,11031401}{3,11031401+3,35468218+3,44591391+3,43651611}=0.23330272 \\
& V_{1}=\frac{3,35468218}{3,11031401+3,35468218+3,44591391+3,43651611}=0.25133551 \\
& V_{3}=\frac{3,44591391}{3,11031401+3,35468218+3,44591391+3,43651611}=0.25817066 \\
& V_{4}=\frac{3,43651611}{3,11031401+3,35468218+3,44591391+3,43651611}=0.25746657
\end{aligned}
$$


4. Based on the calculation of the vector $V$, then the final step is sorting from the greatest value (Table 6).

Table 6. Ranking

\begin{tabular}{ccc}
\hline Alternative & Ranking & Value \\
\hline Employee 1 & 1 & 0.25817066 \\
Employee 2 & 2 & 0.25746657 \\
Employee 3 & 3 & 0.25133551 \\
Employee 4 & 4 & 0.23330272 \\
\hline
\end{tabular}

3.3 System Planning. The system design stage describes the program model that is built, so that a good system can be created. At this stage, the context diagram is described, Hierarchy of Input Process Output (HIPO), Data Flow Diagram (DFD), and Entity Relationship Data (ERD).

3.3.1 Context Diagram. The data streams are described globally to describe the use of data from data sources consisting of three entities, namely administrative staffs, nurses, and leaders. An administrative staff plays a role in the process of data processing criteria, alternative data. Leaders get information on nurse data ranking decisions and reports. The nurse gets the report on the results of the data ranking of the nurse who has the highest value will receive a reward. The context diagram can be seen in Figure 1.

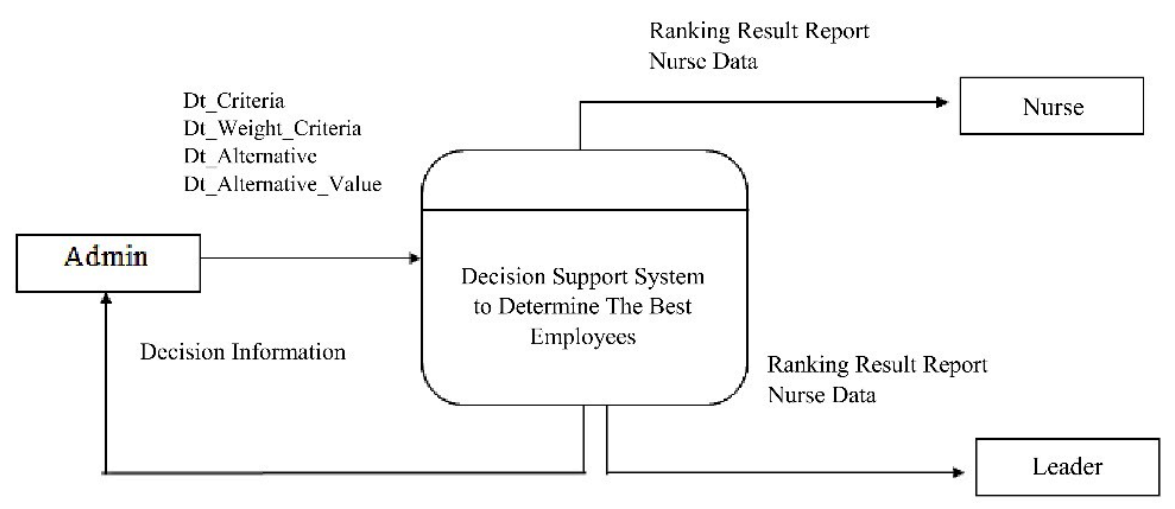

Figure 1. Context Diagram

3.3.2 Input Process Output Hierarchy (HIPO). The earliest system of the decision support system determines the best employees using the analytic hierarchy process and weighted products method before any data derivatives exist. This section consists of input, process and output. The HIPO diagram that the author designed can be seen in Figure 2. 


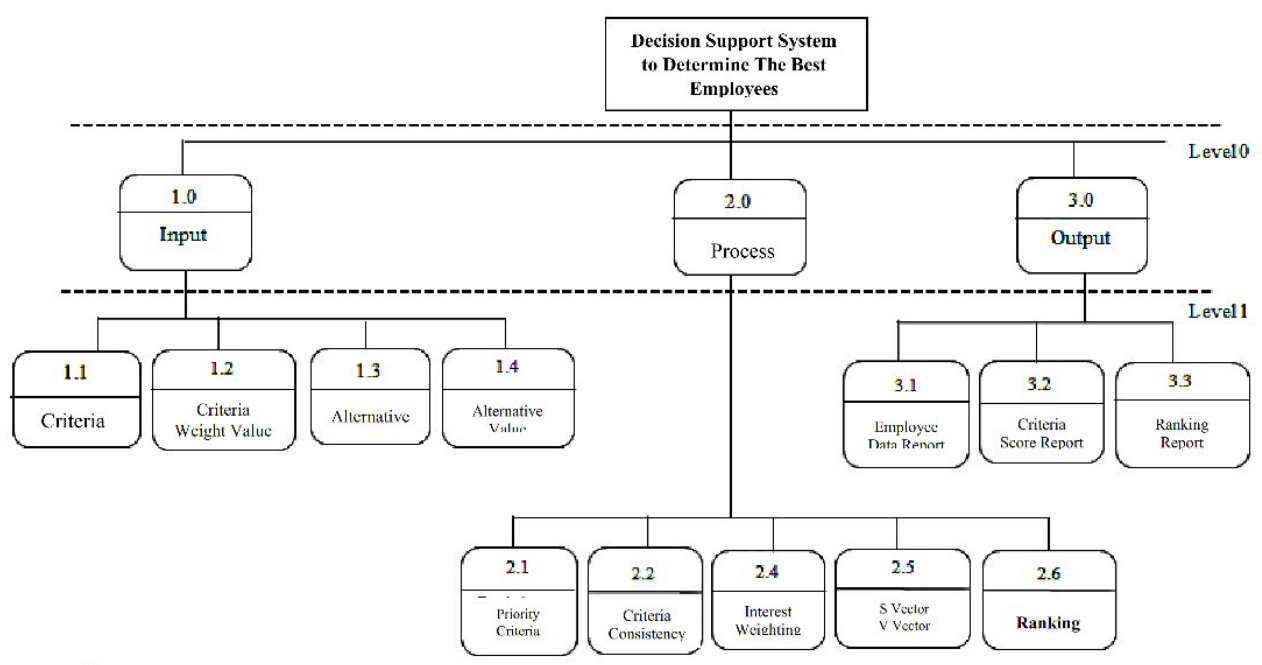

Figure 2. Input Process Output Hierarchy (HIPO)

\subsubsection{Data Flow Diagrams (DFD)}

Data Flow Diagram level 0 that the writer designed for the best employee decision support system using the analytic hierarchy process and weighted product method can be seen in Figure 3.

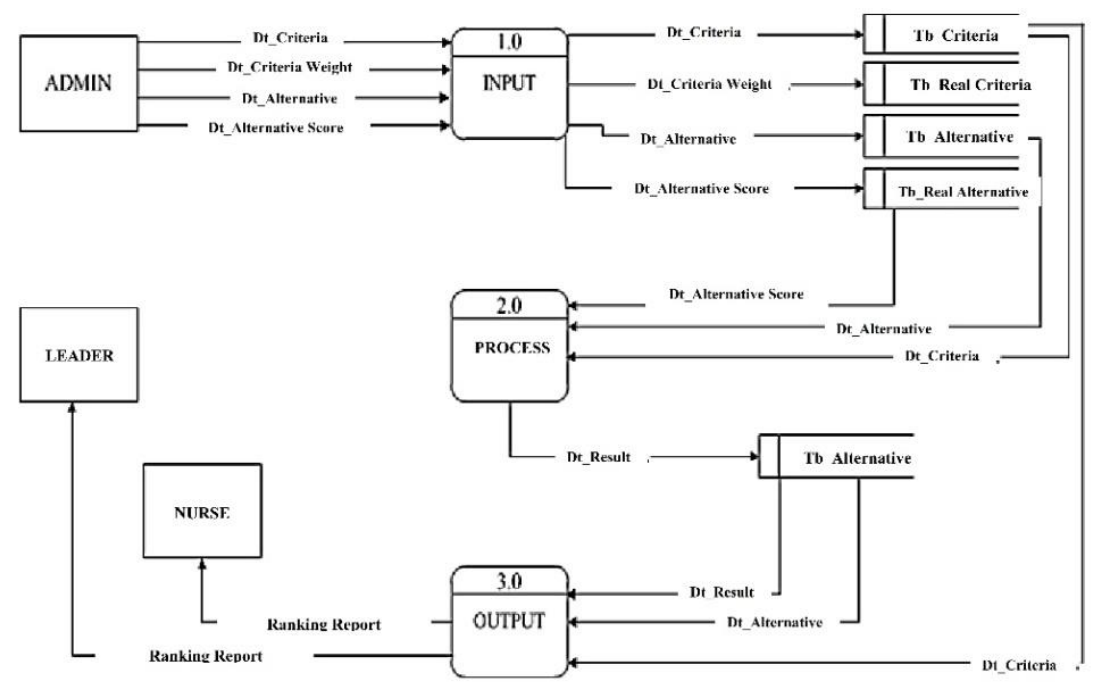

Figure 3. Data Flow Diagrams (DFD) Level 0

\subsection{Implementation}

The system implementation stage is the final stage of developing the SDLC system for the waterfall method, this stage is the stage where all stages and designs that have been made and applications that have been tested are then implemented to determine the best employees. The stages in system development are called the system development 
life cycle because at each stage the system will be carried out sequentially down from planning, analysis, design, implementation and maintenance [9].

The criteria page contains all criteria data that are stipulated in determining the best employees. On this page there is a new criteria data input menu to add new criteria data, an edit menu to change criteria data, a delete menu to delete data and a print menu to print data. There is a lookup table to find criteria code and criteria name for criteria data. The criterion weight value page displays the various categories in each criterion used to determine the best employee. The alternative page displays nurse data and alternative values. On this page there are options for editing alternative weight data. The calculation menu page displays the calculation process using the analytic hierarchy process and weighted product methods based on known criteria. The password menu page is used by the administrative staff to change the password and display the results of employee data ranking.

\subsection{Testing}

3.5.1. Black Box Testing. Program testing is carried out using functional testing to test the specific functions of the application being developed. Test input and output functions regardless of the process [10]. In this test, the correctness of the application being tested is seen based on the output generated from the input data provided. Conclusion of the functionality test results can be seen in Table 7 .

Table 7. Functionality Testing Results

\begin{tabular}{cclc}
\hline No & \multicolumn{1}{c}{ Test Case } & \multicolumn{1}{c}{ Test Item } & Result \\
\hline 1. & Login Verification & Menu Login & Valid \\
2. & Save Data & Form Criteria & Valid \\
& & Form Alternative & Valid \\
& & Form Alternative Value & Valid \\
3. & Search Data & Form Criteria & Valid \\
& & Form Alternative & Valid \\
& & Form Alternative Value & Valid \\
4. & Edit Data & Form Criteria & Valid \\
& & Form Criteria Weight Value & Valid \\
& & Form Alternative & Valid \\
& & Form Alternative Value & Valid \\
5. & Clear Data & Form Criteria & Valid \\
& & Form Alternative & Valid \\
6. & Calculation & Form Calculation & Valid \\
\hline
\end{tabular}


3.5.2. McCall Testing. The McCall method is used to find out whether the software is functioning properly and in accordance with what the user wants later and measures the level of reliability of decision support system applications. McCall's method has good accuracy and detail so that it can be used to test and guarantee the quality of information system software [11]. The results distribution of questionnaires and indicator values can be seen in Table 8, while the analysis of all respondents is shown in Table 9.

Table 8. Results of Questionnaire Distribution and Indicator Values

\begin{tabular}{|c|c|c|c|c|c|c|c|}
\hline \multirow[b]{2}{*}{ Variable } & \multirow[b]{2}{*}{ Dimension } & \multicolumn{2}{|c|}{ Indicator } & \multicolumn{2}{|c|}{ Dimension } & \multicolumn{2}{|c|}{ Variable } \\
\hline & & Mean & $\begin{array}{l}\text { Achieve- } \\
\text { ment }(\%)\end{array}$ & Mean & $\begin{array}{l}\text { Achieve- } \\
\text { ment }(\%)\end{array}$ & Mean & $\begin{array}{l}\text { Achieve- } \\
\text { ment }(\%)\end{array}$ \\
\hline \multirow{4}{*}{ Quality } & \multirow{2}{*}{ Informative } & 4 & 100 & 4 & 100 & 4 & 100 \\
\hline & & 4 & 100 & & & & \\
\hline & \multirow{2}{*}{ Interactive } & 4 & 100 & 4 & 100 & & \\
\hline & & 4 & 100 & & & & \\
\hline Conformity & $\begin{array}{l}\text { Appropriateness } \\
\text { of Information }\end{array}$ & 3.3 & 82.5 & 3.3 & 82.5 & 3.3 & 82.5 \\
\hline \multirow[t]{2}{*}{ Satisfaction } & $\begin{array}{l}\text { Improve the } \\
\text { performance }\end{array}$ & 3 & 75 & 3 & 75 & 3 & 75.0 \\
\hline & Interesting & 3 & 75 & 3 & 75 & & \\
\hline \multirow{4}{*}{ Convenience } & $\begin{array}{l}\text { Easy to Find } \\
\text { Information }\end{array}$ & 3,6 & 90 & 3.6 & 90 & 3,02 & 75.6 \\
\hline & Fasy to use & 2.3 & 57.5 & 2.45 & 61.25 & & \\
\hline & Easy to use & 2.6 & 65 & & & & \\
\hline & Total & & 83.2 & & & & \\
\hline
\end{tabular}

Table 9. Overall Results of Respondents' Ratings

\begin{tabular}{cccc}
\hline Variable & Mean & Percentage & Category \\
\hline Quality & 4 & $100 \%$ & Very Good \\
Conformity & 3.3 & $82.5 \%$ & Very Good \\
Satisfaction & 3 & $75 \%$ & Well \\
Convenience & 3.02 & $75.6 \%$ & Well \\
Result & 3.3 & $83.2 \%$ & Very Good \\
\hline
\end{tabular}

\section{Conclusion}

Decision support system applications for determining the best employees have been created and can be implemented properly. The decision support system testing for determining the best employee uses the Blackbox test method, where the software that is built functionally in the application can run well. The results of the McCall test from the questionnaire data of three administrative staffs after using the application on four nurses data gives an accuracy level of $83.2 \%$. 
Suggestions for using the system that have been made are as follows. It is expected that the application of the best employee decision support system using the Analytic Hierarchy Process and Weighted Product methods can be developed with other calculation methods. In further development, it is hoped that the application can be added for decision making to determine the best employees in all professions, not just nurses.

\section{References}

[1] Hassan, R. and Subasi, A. A decision support system for automated identification of sleep Stages from Single-Channel EEG Signals. Knowledge-Based Systems. Vol. 128, pp. 115-124. 2017.

[2] Masri, M. Penentuan Karyawan Terbaik Dengan Metode Simple Additive Weighting. Journal of Electrical Technology. Vol. 1, No. 1, pp. 36-41. 2016.

[3] Saefudin, M., Abdillah, G., and Yuniarti, R. Sistem Pendukung Keputusan Menentukan Kelayakan Pengangkatan Karyawan Tetap Menggunakan Metode Analytic Hierarchy Process dan Weighted Product, in Seminar Nasional Teknologi Informasi dan Multimedia. Yogyakarta. 2017.

[4] Sywastika, W. Penentuan Lokasi Pemasaran Produk dengan Menerapkan Metode AHP dan WP. Jurnal Manajemen Pemasaran. Vol. 10, No. 2, pp. 155-164. 2016.

[5] Sudinugraha, T. and Mutiara, A. B. Evaluasi Kinerja Dosen Tetap menggunakan Metode AHP dan WP. Jurnal Media Teknologi Informasi dan Komputer. Vol. 1, No. 2, pp. 65-69. 2017.

[6] Putri, S.E., Sovia, R., and Hadi, A. F. Implementasi Sistem Pendukung Keputusan untuk Pemilihan Jurusan Pada Jalur SNMPTN dengan Metode Analitycal Hierarchy Process (Studi Kasus: SMAN 3 Batusangkar), in Seminar Nasional Teknologi Komputer \& Sains. pp. 782-788. 2019.

[7] Ariefiandi, W. A., Abdillah, G., and Ilyas, R. Sistem Pendukung Keputusan Penilaian Kinerja Guru SMA menggunakan Metode Analytical Hierarchy Procces $(A H P)$, in Seminar Nasional Teknologi Informasi dan Multimedia. Yogyakarta. 2017.

[8] Nugraha R. and Abdillah, G. Sistem Pendukung Keputusan Penentuan Desa Terbaik di Kabupaten Cianjur menggunakan Metode Analytic Hierarchy Process dan Weighted Product, in Seminar Nasional Teknologi Informasi dan Multimedia. Yogyakarta. 2018.

[9] Hermawan, R., Hidayat, A. and Utomo, V. G. Sistem Informasi Penjadwalan Kegiatan Belajar Mengajar Berbasis Web. Evolusi: Jurnal Sains dan Manajemen. Vol. 4, No. 1, pp. 72-79. 2016.

[10] Cholifah, W. N. Y. and Sagita, S. M. Pengujian Black Box Testing pada Aplikasi Action \& Strategy berbasis Android dengan Teknologi Phonegap. Jurnal STRING. Vol. 3, No. 2, pp. 206-210. 2018.

[11] Camara, S., Aelani K., and Junior F. D. Pengujian Kualitas Website menggunakan Metode McCall Software Quality. Journal of Information Technology. Vol. 3, No. 1, pp. 25-32. 2021. 